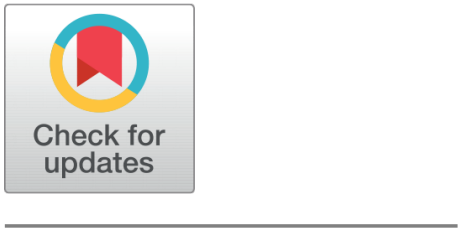

OPEN ACCESS

Received: 21.02.2021

Accepted: 30.03 .2021

Published: 31.07 .2021

Citation: Neelgund HD, Kadadevaru GG (2021) A Study on Seasonal Variation in Zooplankton Abundance in Kadasgatti Minor Irrigation Tank of Bailhongal Taluk, Belagavi District, Karnataka State, INDIA.. Indian Journal of Science and Technology 14(27): 2238-2249. https://doi.org/

10.17485/IJST/v14i27.323

* Corresponding author.

kadadevarug@gmail.com

Funding: None

Competing Interests: None

Copyright: (c) 2021 Neelgund \& Kadadevaru. This is an open access article distributed under the terms of the Creative Commons Attribution License, which permits unrestricted use, distribution, and reproduction in any medium, provided the original author and source are credited.

Published By Indian Society for Education and Environment (iSee)

ISSN

Print: 0974-6846

Electronic: 0974-5645

\section{A Study on Seasonal Variation in Zooplankton Abundance in Kadasgatti Minor Irrigation Tank of Bailhongal Taluk, Belagavi District, Karnataka State, INDIA.}

\author{
Harsha D Neelgund ${ }^{1}$, Girish G Kadadevaru ${ }^{2 *}$ \\ 1 Department of Zoology, Karnatak Science College, Dharwad, 580001, Karnataka, India \\ 2 Department of Zoology, Karnatak University, Pavate Nagar, Dharwad, 580003, Karnataka, \\ India
}

\section{Abstract}

Objectives: A study on seasonal variation in zooplankton community was undertaken to evaluate the present status of water quality at Kadasgatti minor irrigation tank (MIT) located in the northern transitional zone of Belagavi district. Methods and Statistical Analysis: Water samples were collected from January 2017 to December 2017. Physico-chemical parameters and qualitative and quantitative analysis of zooplankton were carried out. Pearson correlation was calculated using SPSS, IBM Version 21 software to find out interrelationships between water quality and zooplankton groups. Findings: A total of 52 species of zooplanktons were recorded during the study period with a total zooplankton abundance of 14327 individuals with a relative abundance of $35.42 \%$. Rotifera was the dominant group with 27 species, followed by Cladocera, Copepoda and Ostracoda. The highest zooplankton abundance was observed in summer while minimum in post-monsoon season. Copepoda was highest abundant group during the entire study period with its maximum abundance during winter and gradually declined and reached to its minimum in post-monsoon. The presence of eutrophic indicator species like Brachionus calyciflorus, Brachionus angularis, Filina longiseta suggests eutrophication of the tank. Novelty: The study provides baseline data on the present status of the water body indicating that, anthropogenic activities, agricultural runoff are the main cause of eutrophication. Sustainable and holistic conservational strategies have to be adopted to protect the water body.

Keywords: Cladocera; Copepoda; Eutrophication; Rotifera; Seasonal variation; Zooplankton abundance

\section{Introduction}

Zooplankton occupies a critical position in the food web and is food for many fishes, aquatic insects and other zooplankton. These are more valuable as indicators of tropic conditions and respond more rapidly to the environmental changes than fishes ${ }^{(1-4)}$. The structure of plankton community depends on complex factors like; morphometric 
and regional climatic conditions, which govern the important physical and chemical characteristics of water-bodies determined by edaphic features and vegetation on the diversity of the plankton ${ }^{(5)}$. The changes in zooplankton abundance, species diversity and its community composition are usually considered to be the best indicator of environmental changes ${ }^{(6)}$. The density and diversity of the zooplankton are controlled by the several physico-chemical factors of water ${ }^{(7)}$.

Internationally there are several studies on zooplanktons which include structure of zooplankton populations in the littoral macrophyte zone of Colorado lakes ${ }^{(8)}$; Life history patterns in zooplanktons ${ }^{(9)}$; Spatial and temporal patterns in distribution of zooplankton in Jurumirim Reservoir of Sao Paulo, Brazil ${ }^{(10)}$; Seasonal variations of zooplankton abundance in the freshwater reservoir Valle de Bravo (Mexico) ${ }^{(11)}$; Effects of hydrology on plankton biomass in shallow lakes ${ }^{(12)}$; Overwintering strategies of copepods ${ }^{(13)}$; Zooplankton response to extreme drought in a large subtropical lake ${ }^{(14)}$; Contrasting effects of chemical and thermal variability on lake zooplankton abundance in temperate zone lakes of North America and Europe ${ }^{(15)}$; Spatial distribution of zooplankton diversity in temporary pools of semiarid regions of Brazil ${ }^{(16)}$; Influence of bioclimatic factors on species richness in ponds and lakes of Albania and North Macedonia ${ }^{(17)}$; Zooplankton biodiversity monitoring in polluted freshwater ecosystems of China ${ }^{(18)}$.

Baird $^{(19)}$ and Anderson ${ }^{(20)}$ initiated taxonomic studies on Indian freshwater Cladocera and Rotifera respectively. Subsequently there are several reports on zooplankton studies from different parts of India that includes the studies on zooplankton composition in the limnetic zones of two subtropical lakes, Nainital and the Bhimtal of Uttar Pradesh, India ${ }^{(21)}$. Investigations on rotifer, cladocera and copepoda group has been carried out from eastern, North West and North East part of India ${ }^{(22-26)}$. Zooplankton emergence pattern and resting egg diversity of dried water bodies in north Maharashtra ${ }^{(27)}$.

In southern India, limnological studies and distribution of micro and macro-invertebrates have been studied from Hyderabad $^{(28)}$ and Telangana ${ }^{(29,30)}$; Preliminary survey of plankton in Irrukkagudi reservoir in Tamil Nadu ${ }^{(4)}$; A new species, Megadiaptomus Kiefer, 1936 was reported from the Western Ghats ${ }^{(31)}$; The first report of freshwater rotifers from south Andaman $^{(32)}$.

Karnataka is one of the agriculturally and industrially leading states in India. It is also known for its large number of water-bodies like, small impoundments and bigger tanks, which are mainly used for irrigation, fisheries, washing, bathing etc. The studies in Karnataka include characterization of some selected lentic habitats of Dharwad, Haveri and Uttara Kannada districts ${ }^{(33,34)}$; Diversity and seasonal fluctuation of zooplankton from fish ponds of Bhadra fish farm ${ }^{(35)}$; Monthly changes in the abundance and biomass of zooplankton and water quality parameters in Kukkarahalli lake and zooplankton abundance of Kalale, Alanahalli and Dalvoy lakes of Mysore ${ }^{(36,37)}$; Water quality assessment of Almatti Reservoir of Bijapur ${ }^{(38)}$; Trophic status of three fresh water lakes of Gulbarga ${ }^{(39)}$; Zooplankton studies of Tungabhadra river near Harihar ${ }^{(40)}$. Studies on zooplankters of Belagavi district are restricted to the rotifer diversity, water quality assessment of fort lake, Belgaum ${ }^{(41)}$ and Sogal pond ${ }^{(42)}$.

Seasonal studies on zooplankton abundance of a given water body not only explain the factors responsible for the presence or absence of certain taxa but also interpret changes in the patterns of species diversity in addition it will also help in assessment of water body to evaluate its present status. As there are no such reports from Bailhongal taluk, the present work was undertaken to study the species richness, diversity, abundance and seasonal variations in zooplankton at Kadasgatti minor irrigation tank (MIT).

\section{Materials and Methods}

\subsection{Study area:}

Belagavi district is located east of the Western Ghats and is situated in the northwest part of Karnataka state and it lies $15^{\circ} 00$ and $17^{\circ} 00$ north latitudes and between $74^{\circ} 00^{\prime}$ and $75^{\circ} 30^{\prime}$ east longitude. Its topography is predominantly undulating. The terrain marks with hilly region at the western parts of Khanapur and Belagavi taluk. Agro-climatically, the district can be divided into three zones; hilly zone, northern transitional zone and northern dry zone. Kadasgatti MIT falls in Bailhongal taluk at $15.639193 \mathrm{~N}, 74.873916 \mathrm{E}$ that lies in the northern transitional zone. It has the catchment area of $15.54 \mathrm{~km}^{2}$ with water spread area of 1,03,819.72 $\mathrm{m}^{2}$ and located $680.06 \mathrm{~m}$ above sea level. The average rainfall in this area is $862 \mathrm{~mm}$ (Figure 1). 


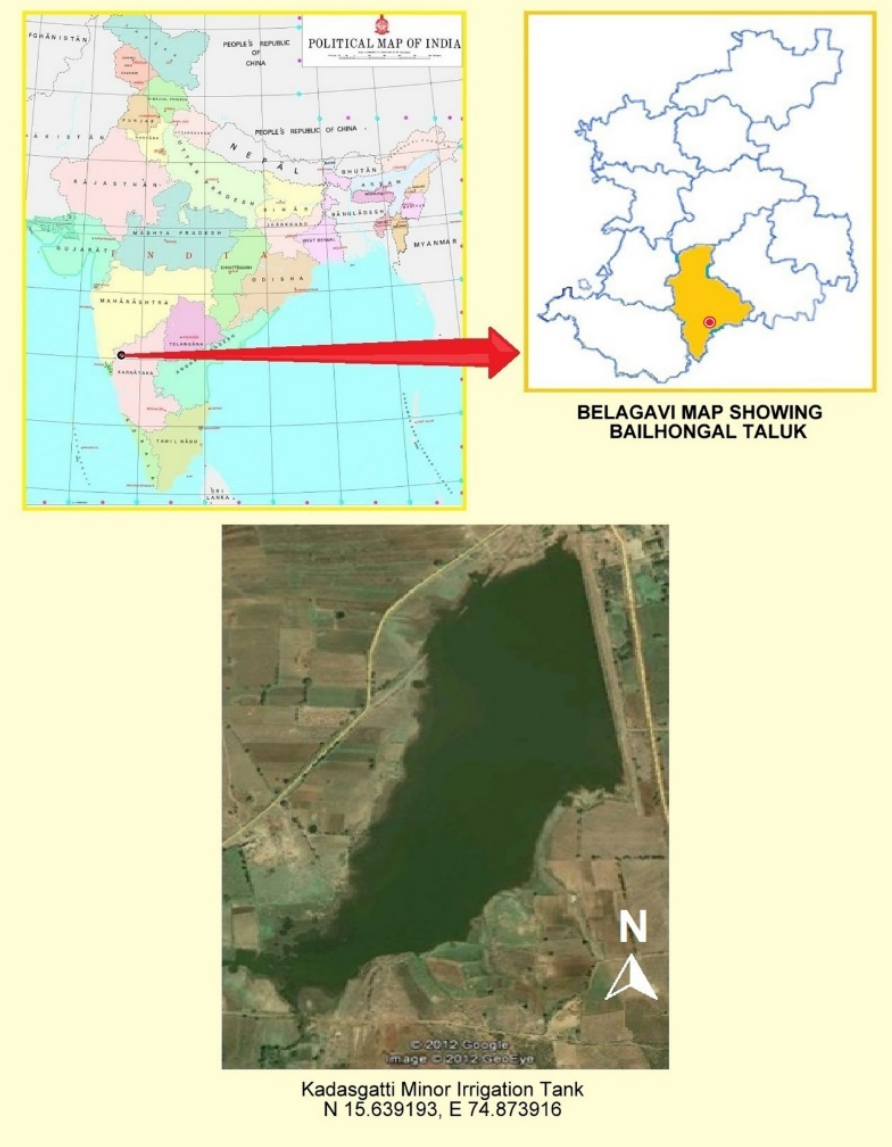

Fig 1. Map of study area showing Kadasgatti Minor Irrigation Tank (MIT) of Bailhongal, Belagavi District, Karnataka State, INDIA.

\subsection{Physico-chemical and Plankton Analysis:}

For the present study water samples were collected at monthly intervals from January, 2017 to December, 2017 between 6:00 am to 10:30 am. Physical factors like atmospheric and water temperature were measured at the study site by using mercury thermometer, transparency by secchi disk and humidity by hygrometer. Eutech PS Testr 35 multi-parameter probe was used to measure $\mathrm{pH}$, electric conductivity (EC), total dissolved solids (TDS) and salinity in the field itself. For measuring other parameters samples were brought to the laboratory and estimations were carried out by following standard methods mentioned in APHA ${ }^{(43)}$. For the plankton study, water was collected from the surface with minimal disturbance and filtered in a plankton net made of nylon bolting cloth $(30 \mathrm{~cm}$ in diameter and $68 \mu \mathrm{m}$ pore size). The volume of water sieved for zooplankton analysis was 100 litres. The sieved samples stored in 1 litre bottles were preserved by adding $3 \mathrm{ml}$ of $4 \%$ formalin. The preserved samples were kept for 24 hours undisturbed to allow the sedimentation of plankton suspended in the water. After that, the supernatant was discarded carefully without disturbing the sediments and the final volume of concentrated sample was $120 \mathrm{ml}$. The qualitative and quantitative analysis was performed by Lackey's drop count method using MAGNUS MLX - TR optical compound binocular microscope. Species identification was carried out by using available taxonomic keys ${ }^{(6,22,24,25,32,44-52)}$. SPSS, IBM Version 21 software was used for statistical analysis. Pearson correlation was formed to find interrelation between zooplankton groups and physicochemical factors. 


\section{Results and Discussion:}

The maximum and minimum values and seasonal variations in physico-chemical factors recorded from January 2017 to December, 2017 and their interrelationships with zooplankton groups are summarized (Tables 1 and 4).

Table 1. Maximum and minimum values of physicochemical factors of in Kadasgatti MIT of Bailhongal taluk during January, 2017 to December, 2017.

\begin{tabular}{lll}
\hline Parameters & Maximum Value & Minimum Value \\
\hline Atm Tempt, ${ }^{\circ} \mathrm{C}$ & 29 & 10 \\
Water Tempt, ${ }^{\circ} \mathrm{C}$ & 27.1 & 16 \\
Transparency, cm & 45 & 58 \\
Humidity, $\%$ & 79 & 7.8 \\
$\mathrm{pH}$ & 9.48 & 0.9 \\
Salinity, ppm & 629 & 1.53 \\
TDS, ppm & 891 & 2.12 \\
EC, $\mu$ S/cm & 1299 & 3.225 \\
DO, mg/Lt & 9.137 & 2.2 \\
Free CO2, mg/Lt & 85.8 & 6.65 \\
Total Alkalinity, mg/Lt & 216.5 & 28 \\
Total Hardness, mg/Lt & 420.69 & 12.297 \\
Chloride, mg/Lt & 690.97 & 6 \\
Sulphate, mg/Lt & 26 & 10 \\
Nitrates, mg/Lt & 30 & 16.4 \\
COD, mg/Lt & 228 & 4.86 \\
BOD, mg/Lt & 84.8 & 0.01 \\
Phosphates, mg/Lt & 0.3 & 14 \\
Rainfall, mm & 155 & \\
\hline
\end{tabular}

During the 12 month study, a total of 52 species of zooplankters were recorded. Rotifera was the dominant group represented with 27 species followed by Cladocera with 14 species, Copepoda with 8 species and only three species were recorded from Ostracoda (Table 2). Seasonal variations in zooplankters reveals that, maximum of 4821 individuals were recorded during summer followed by 4045 in winter, 3092 in monsoon and a minimum of 2369 individuals during post-monsoon respectively (Figure 2).

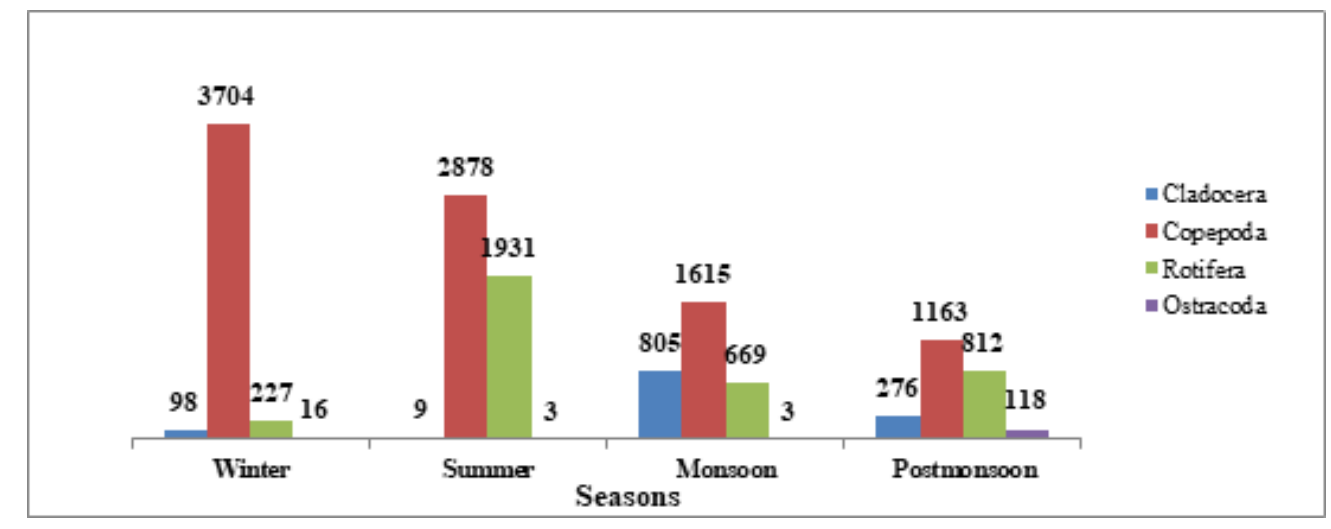

Fig 2. Seasonal variation in zooplankton abundance recorded in Kadasgatti MIT from January to December, 2017 
Table 2. Seasonal variations in zooplankton abundance (ind/L) of Kadasgatti MIT from January, 2017 to December, 2017

\begin{tabular}{|c|c|c|c|c|}
\hline Zooplankton / Season & $\begin{array}{l}\text { Winter } \\
\text { (Jan to Feb) }\end{array}$ & $\begin{array}{l}\text { Summer } \\
\text { (Mar to May) }\end{array}$ & $\begin{array}{l}\text { Monsoon } \\
\text { (Jun to Sept) }\end{array}$ & $\begin{array}{l}\text { Post-monsoon } \\
\text { (Oct to Dec) }\end{array}$ \\
\hline \multicolumn{5}{|l|}{ CLADOCERA } \\
\hline Alona Baird, 1843 & 2 & 1 & 0 & 4 \\
\hline Alonella GO Sars, 1862 & 12 & 0 & 0 & 1 \\
\hline Bosminopsis deitersi Richard, 1985 & 0 & 0 & 0 & 19 \\
\hline Bosmina longirostris O.F Muller, 1776 & 12 & 0 & 0 & 7 \\
\hline Bipertura karua & 0 & 0 & 0 & 3 \\
\hline Ceriodaphnia corunata & 49 & 1 & 0 & 37 \\
\hline Diaphanosoma exicusm Sars, 1885 & 0 & 0 & 4 & 28 \\
\hline Diaphanosoma sarsi Richard, 1894 & 2 & 0 & 72 & 60 \\
\hline Echinisca odiosa & 2 & 0 & 0 & 0 \\
\hline Macrothrix goeldi Richard, 1897 & 1 & 0 & 4 & 2 \\
\hline Macrothrix spinosa King, 1853 & 3 & 0 & 0 & 0 \\
\hline Moina micrura Kurz, 1875 & 15 & 1 & 648 & 105 \\
\hline Moina brachiate Jurine, 1820 & 0 & 4 & 60 & 0 \\
\hline Moina daphnia & 0 & 2 & 17 & 10 \\
\hline Total & 98 & 9 & 805 & 276 \\
\hline \multicolumn{5}{|l|}{ COPEPODA } \\
\hline Heliodiaptomus viddus Gurney, 1916 & 129 & 0 & 278 & 305 \\
\hline Sinediaptomus indicus & 109 & 0 & 12 & 308 \\
\hline Neodiaptomus strigilipes & 76 & 0 & 0 & 468 \\
\hline Paracyclops fimbriatus Fischer, 1853 & 1024 & 1094 & 604 & 20 \\
\hline Paracyclops psilosus & 0 & 18 & 0 & 0 \\
\hline Tropocyclops prasinus Fischer, 1860 & 923 & 744 & 455 & 23 \\
\hline Mesocyclops leuckarti Claus, 1857 & 951 & 299 & 211 & 3 \\
\hline Thermocyclops hyalinus Rehberg, 1880 & 455 & 117 & 31 & 1 \\
\hline Nauplii & 37 & 606 & 24 & 35 \\
\hline Total & 3704 & 2878 & 1615 & 1163 \\
\hline \multicolumn{5}{|l|}{ ROTIFERA } \\
\hline Anueropsis coelata & 7 & 11 & 0 & 24 \\
\hline Anueropsis fissa & 1 & 13 & 0 & 0 \\
\hline Anueropsis navicula & 0 & 10 & 0 & 0 \\
\hline Brachionus leydigi Cohn, 1862 & 10 & 0 & 0 & 28 \\
\hline Brachionus plicatilis Gosse, 1851 & 4 & 16 & 2 & 4 \\
\hline Brachionus rubens Ehrenberg, 1838 & 3 & 28 & 2 & 9 \\
\hline Brachionus caudatus Barrois \& Daday, 1894 & 5 & 25 & 1 & 11 \\
\hline Brachionus urceolaris Muller, 1773 & 2 & 11 & 0 & 6 \\
\hline Brachionus diversicornis Daday, 1883 & 6 & 13 & 0 & 16 \\
\hline Brachionus angularis Gosse, 1857 & 6 & 7 & 569 & 56 \\
\hline Brachionus calyciflorus Pallas, 1766 & 13 & 2 & 23 & 0 \\
\hline Brachionus calyciflorus var. dorcus & 3 & 13 & 11 & 15 \\
\hline Brachionus quadridentata & 1 & 4 & 3 & 7 \\
\hline Filina longiseta & 0 & 1194 & 9 & 0 \\
\hline Filina opoliensis & 3 & 25 & 18 & 2 \\
\hline Lepadella biloba Hauer, 1958 & 45 & 5 & 0 & 6 \\
\hline Lepadella rhomboides Gosse, 1886 & 52 & 0 & 1 & 3 \\
\hline Lepadella sp. & 21 & 0 & 3 & 27 \\
\hline Lacinularia socialis & 0 & 0 & 0 & 51 \\
\hline Pompholyx sulcata Hudson, 1885 & 2 & 5 & 0 & 2 \\
\hline Philodina Erhenberg, 1830 & 0 & 373 & 0 & 4 \\
\hline Rotifer tardus Erhenberg, 1838 & 24 & 51 & 0 & 4 \\
\hline Sinantherina sp. & 0 & 34 & 0 & 537 \\
\hline Keratella tropica Apstein, 1907 & 8 & 1 & 27 & 0 \\
\hline Lecane stenroosi Meissner, 1908 & 3 & 2 & 0 & 0 \\
\hline
\end{tabular}




\begin{tabular}{lllll}
\hline Table 2 continued & & & & \\
\hline Polyarthra Ehrenberg, 1834 & 0 & 84 & 0 & 0 \\
Rotaria neptunia Erhenberg, 1830 & 8 & 4 & 0 & 0 \\
\hline Total & 227 & 1931 & 669 & 812 \\
\hline OSTRACODA & & & 0 & 11 \\
\hline Hemicypris fossulata & 3 & 1 & 3 & 72 \\
Ilyocypris sp. & 10 & 2 & 0 & 35 \\
Stenocypris sp. & 3 & 0 & 3 & 118 \\
Total & 16 & 3 & \\
\hline
\end{tabular}

Copepoda was the most abundant group that was observed throughout the study period. Their occurrence was highest in winter (92\%) and declined gradually in summer (60\%) to monsoon (52\%) and minimum in post-monsoon (49\%) (Figures 3, 4, 5 and 6). Cyclopoids like Paracyclops fimbriatus, Tropocyclops prasinus, Mesocyclops leuckarti and Thermocyclops hyalinus were the major contributors for the maximum abundance. Similar observations were made at the Almatti reservoir of Bijapur ${ }^{(38)}$. In the present study, calanoids were absent during summer while cyclopoids were present in all the seasons except Paracyclops psilosus which was recorded only during summer. Copepoda shows a positive correlation with Sulphate (Table 4). Sent it separate sheet

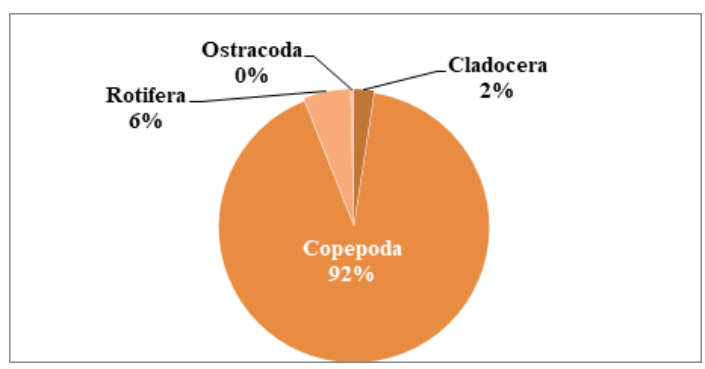

Fig 3. Abundance of zooplankton groups during the winter season in Kadasgatti MIT

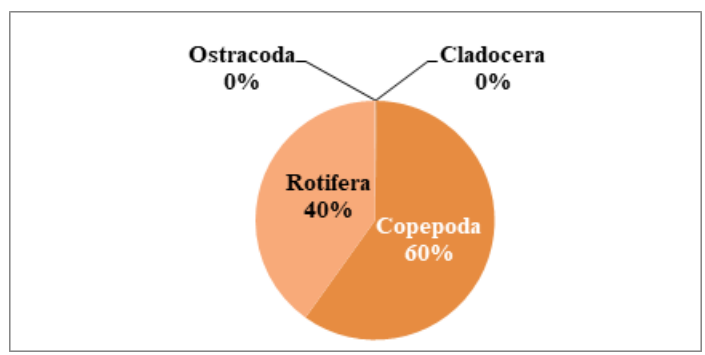

Fig 4. Abundance of zooplankton groups during the summer season in Kadasgatti MIT

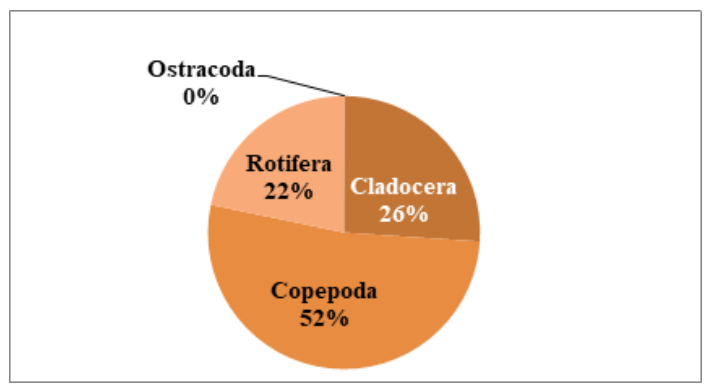

Fig 5. Abundance of zooplankton groups during the monsoon season in Kadasgatti MIT 


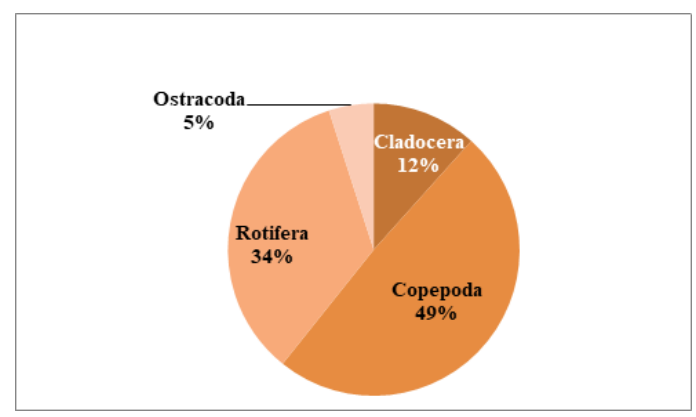

Fig 6. Abundance of zooplankton groups recorded during the post-monsoon season in Kadasgatti MIT

Rotifers play an important role as suspension feeders among the zooplankton community. They exhibit marked differences in their tolerance and adaptability to changes in the physicochemical and biological factors ${ }^{(53)}$. Several studies indicated that rotifer abundance generally increase during summer ${ }^{(10,11,42,53-58)}$. In the present study Rotifers were represented with 27 species exhibiting the highest species richness and their abundance was highest during summer (40\%), and least in winter (6\%). Contreras et al., ${ }^{(59)}$ also observed lowest density of rotifers during winter and highest during summer. Higher rotifer assemblage in summer can be attributed to the hyper-tropical conditions of the water body with high temperature and low water level ${ }^{(60,61)}$. Dominance and abundance of rotifers are associated with the increase in trophic conditions due to their capability to ingest smaller organisms like bacteria and other organic detritus, which are abundant in eutrophic ecosystem. Brachionus calyciflorus is considered to be a good indicator of eutrophication. Brachionus angularis, Filina longiseta and Lecane sp. are indicators of semi-polluted waters ${ }^{(62)}$. In the present study, Filina longiseta was the most abundant species with the highest abundance of 1194 individuals observed in summer. According to Hutchinson ${ }^{(63)}$, Brachionus species are very common in temperate and tropical waters. Presence of Brachionus plicatilis, B rubens, $B$ caudatus, $B$ angularis, $B$ calyciflorus var. dorcus and $B$ quadridentata throughout the study period indicates their ability to tolerate varying ecological conditions. Keratella tropica is stenothermal species that was least during summer and highest during monsoon whereas, Brachionus angularis, Brachionus calyciflorus, Brachionus rubens, Polyarthra sp are eurythermal ${ }^{(64)}$. Except Polyarthra sp. other species were present throughout the study period. Several studies report decline of rotifers in monsoon ${ }^{(29,65)}$. Decline of rotifers during monsoon can be interpreted to the dilution factors. Inflow of water during rains can affect the feeding habitat of zooplankton ${ }^{(55)}$. In the present study also we report minimum rotifers during monsoon. Rotifers showed positive correlation with COD and Phosphate (Table 4). In the present study, the rotifer abundance increased (1931 ind/ L) with increase in Phosphate concentration (0.3mg/L) in summer and its decreased (669ind/L) with the decrease in phosphate concentration during monsoon. Major source of phosphorus in most of the waterbodies is municipal and agricultural runoffs.

A total of 14 species of Cladocera were recorded from the water body during the study period. They were abundant in monsoon and in post-monsoon and their number was drastically reduced to 9 individuals in summer. Cladoceran increase during monsoon season was also reported in earlier studies ${ }^{(35,54)}$. Monsoon season might have favored their abundance due increase in transparency, reduced water temperatures and availability of food. Cladocera were abundant when the temperature and salinity values were low and dissolved oxygen was more in the environment. They exhibited positive correlation with rainfall (Table 4). Salinity forms one of the most influential environmental variables in aquatic ecosystems ${ }^{(66)}$. Cladocera are highly sensitive to salinity and salinity concentration restricts the survival of most large bodied cladocerans compared to other zooplankton groups ${ }^{(67)}$ and electric conductivity can be considered as an indirect measure of salinity ${ }^{(68)}$. Green ${ }^{(69)}$ quotes that 'a decrease in the relative abundance of cladocerans in microcrustacean zooplankton as salinity increases'. Many cladocera, especially daphnids, do not survive at salinity values above 3-4 per mille ${ }^{(70,71)}$. During the study, highest salinity (629ppm) was recorded during May, 2017 (summer) during which lowest abundance of cladocera with 9 individuals were recorded. Moina micrura appeared to be the major contributor for cladoceran abundance

Ostracods were represented with 16 individuals during winter whereas declined in summer and monsoon season with 3 individuals. During post-monsoon they elevated to 118 individuals. Ilyocypris sp. was the highest recorded species among ostracods that was found throughout the study period. Most freshwater ostracods prefer alkaline or slightly acidic waters although some have been reported to tolerate wide range of $\mathrm{pH}^{(72)}$. In the present study, the water was found alkaline throughout the study. Ostracods being the least abundant group exhibited positive correlation with transparency, total alkalinity and total hardness (Table 4). 
The total zooplankton abundance recorded at Kadasgatti MIT was 14327 individuals. The Dominance value recorded is 0.0930; Simpson_1-D value recorded is 0.9069 ; Shannon Diversity $(H)$ valve recorded is $H=2.788$ while Evenness (E) value is $\mathrm{E}=0.7023$ (Table 3).

Table 3. Abundance, Relative abundance, Dominance, Simpson, Shannon Diversity and Evenness of the Kadasgatti Minor irrigation tank of Bailhongal taluk, Belagavi District

\begin{tabular}{|c|c|c|c|}
\hline CLADOCERA & Abn. & ROTIFERA & Abn. \\
\hline Alona Baird, 1843 & 7 & Anueropsis coelata & 42 \\
\hline Alonella GO Sars, 1862 & 13 & Anueropsis navicula & 10 \\
\hline Bosminopsis deitersi Richard, 1985 & 19 & Anueropsis fissa & 14 \\
\hline Bosmina longirostris O.F Muller, 1776 & 19 & Brachionus caudatus Barrois \& Daday, 1894 & 42 \\
\hline Bipertura karua & 3 & Brachionus leydigi Cohn, 1862 & 38 \\
\hline Ceriodaphnia corunata & 87 & Brachionus diversicornis Daday, 1883 & 35 \\
\hline Diaphanosoma exicusm Sars, 1885 & 32 & Brachionus angularis Gosse, 1857 & 638 \\
\hline Diaphanosoma sarsi Richard, 1894 & 134 & Brachionus calyciflorus Pallas, 1766 & 38 \\
\hline Echinisca odiosa & 2 & Brachionus calyciflorus var. dorcus & 42 \\
\hline Macrothrix goeldi Richard, 1897 & 7 & Brachionus quadridentata & 15 \\
\hline Macrothrix spinosa King, 1853 & 3 & Brachionus rubens Ehrenberg, 1838 & 42 \\
\hline Moina micrura Kurz, 1875 & 769 & Brachionus urceolaris Muller, 1773 & 19 \\
\hline Moina brachiata Jurine, 1820 & 64 & Brachionus plicatilis Gosse, 1851 & 26 \\
\hline Moina daphnia & 29 & Filina opoliensis & 48 \\
\hline COPEPODA & & Filina longiseta & 1203 \\
\hline Heliodiaptomus viddus Gurney, 1916 & 712 & Lacinularia socialis & 51 \\
\hline Sinediaptomus indicus & 429 & Lepadella rhomboides Gosse, 1886 & 56 \\
\hline Neodiaptomus strigilipes & 544 & Lepadella biloba Hauer, 1958 & 56 \\
\hline Paracyclops fimbriatus Fischer, 1853 & 2742 & Lepadella sp. & 51 \\
\hline Paracyclops psilosus & 18 & Lecane stenroosi Meissner, 1908 & 5 \\
\hline Tropocyclops prasinus Fischer, 1860 & 2145 & Pompholyx sulcata Hudson, 1885 & 9 \\
\hline Mesocyclops leuckarti Claus, 1857 & 1464 & Polyarthra Ehrenberg, 1834 & 84 \\
\hline Thermocyclops hyalinus Rehberg, 1880 & 604 & Philodina Erhenberg, 1830 & 377 \\
\hline Nauplii & 702 & Keratella tropica Apstein, 1907 & 36 \\
\hline OSTRACODA & & Sinantherina sp. & 571 \\
\hline Hemicypris fossulata & 15 & Rotifer tardus Erhenberg, 1838 & 79 \\
\hline Ilyocypris sp. & 87 & Rotaria neptunia Erhenberg, 1830 & 12 \\
\hline Stenocypris sp. & 38 & & \\
\hline Abundance & 14327 & Shannon_H & 2.788 \\
\hline Dominance_D & 0.0930 & Evenness_E & 0.7023 \\
\hline Simpson_1-D & 0.9069 & Note: Abn - Abundance & \\
\hline
\end{tabular}

\section{Conclusion}

Fifty two species of zooplanktons were recorded in Kadasgatti Minor irrigation tank. Rotifers were represented with highest species richness with 27 species and their abundance was maximum during summer. Copepods were the most abundant groups and they were found in maximum number during winter declined gradually and their minimum abundance was observed during post-monsoon. Filina longiseta was a rotifer was the most abundant species in the water body. Cladocera and Ostracoda groups preferred higher water levels and water transparency and lower temperature. Hence their abundance was observed during monsoon and post-monsoon seasons.

Anthropogenic activities, agricultural runoff and presence of eutrophic indicator species like Brachionus calyciflorus, Brachionus angularis, Filina longiseta and Lecane sp. suggests the eutrophication of water body. The study provides a baseline data on the present status of the water body. In order to protect the water body from further degradation, authorities need to focus on adopting the sustainable and holistic approach for its maintenance and conservation.

\section{Acknowledgements}

Authors thank Mr Manjunath Hosamani for his assistance during field collection and Mr Akshay Deshpande and Mr Basavaraj $\mathrm{K}$ in the preparation of the manuscript. 


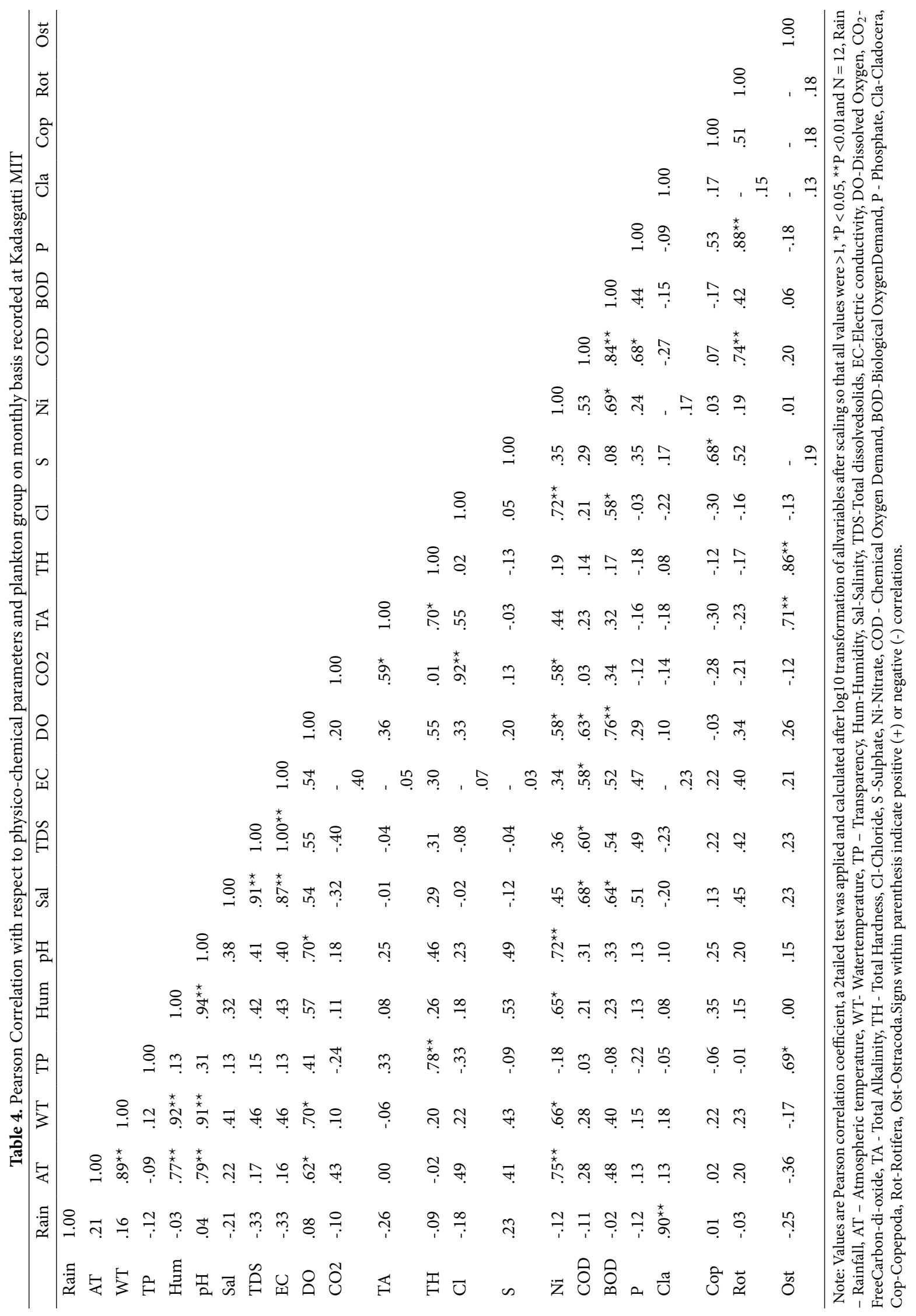




\section{References}

1) Wetzel RG. Limnology. 1975. Available from: https://doi.org/10.1002/iroh.19780630619.

2) Gannon JE, Stemberger RS. Zooplankton (Especially Crustaceans and Rotifers) as Indicators of Water Quality. Transactions of the American Microscopical Society. 1978;97(1):16-35. Available from: https://dx.doi.org/10.2307/3225681.

3) Vladimir S. Rotifers as indicators of water quality. Hydrobiologia. 1983;100:169-201.

4) Kanagasabapathi V, Rajan MK. A prelimnary survey of plankton in Irrukkangudi Reservoir. India Journal of Phytology. 2010;2(3):63-72. Available from: http://updatepublishing.com/journal/index.php/jp/article/view/2101.

5) Neves IF, Rocha O, Roche KF, Pinto AA. Zooplankton community structure of two marginal lakes of the River Cuiabá (Mato Grosso, Brazil) with analysis of Rotifera and Cladocera diversity. Brazilian Journal of Biology. 2003;63(2):329-343. Available from: https://dx.doi.org/10.1590/s1519-69842003000200018.

6) Sharma S, Sharma BK. Zooplankton diversity in floodplain lakes of Assam. Records of the Zoological Survey of India. 2008;p. 1-307. Available from: http://faunaofindia.nic.in/PDFVolumes/occpapers/290/index.pdf.

7) Nair NB, Kumar KK, Arunachalam M, Azis PKA, Dharmaraj K. Ecology of Indian estuaries: Studies on the zooplankton ecology of Kadinamkulam Backwater. Proceedings: Animal Sciences. 1984;93(6):573-584. Available from: https://dx.doi.org/10.1007/bf03186307.

8) Pennak RW. Structure of Zooplankton Populations in the Littoral Macrophyte Zone of Some Colorado Lakes. Transactions of the American Microscopical Society. 1966;85(3):329-329. Available from: https://dx.doi.org/10.2307/3224313.

9) Allan JD. Life History Patterns in Zooplankton. The American Naturalist. 1976;110(971):165-180. Available from: https://dx.doi.org/10.1086/283056.

10) Nogueira M, Gomes. Zooplankton composition, dominance and abundance as indicators of environmental compartmentalization in Jurumirim Reservoir (Parana panema River). Hydrobiologia. 2001;455:1-18. Available from: https://link.springer.com/article/10.1023/A:1011946708757.

11) Ramirez GP, Nandini S, Sarma S, Valderrama R, Cuesta E, Hurtado I, et al. Seasonal variations of zooplankton abundance in the freshwater reservoir Valle de Bravo (Mexico). Hydrobiologia. 2002;467:99-108. Available from: https://doi.org/10.1080/07438140809354842.

12) Rennella AM, Quirós R. The Effects of Hydrology on Plankton Biomass in Shallow Lakes of the Pampa Plain. Hydrobiologia. 2006;556(1):181-191. Available from: https://dx.doi.org/10.1007/s10750-005-0318-y.

13) Wesche A, Wiltshire KH, Hirche HJ. Overwintering strategies of dominant calanoid copepods in the German Bight, southern North Sea. Marine Biology. 2007;151(4):1309-1320. Available from: https://dx.doi.org/10.1007/s00227-006-0560-5.

14) Havens KE, East TL, Beaver JR. Zooplankton response to extreme drought in a large subtropical lake. Hydrobiologia. 2007;589(1):187-198. Available from: https://dx.doi.org/10.1007/s10750-007-0738-y.

15) Shurin JB, Winder M, Adrian R, Keller WB, Matthews B, Paterson AM, et al. Environmental stability and lake zooplankton diversity - contrasting effects of chemical and thermal variability. Ecology Letters. 2010;13(4):453-463. Available from: https://dx.doi.org/10.1111/j.1461-0248.2009.01438.x.

16) Melo TX, Medeiros ESF. Spatial Distribution of Zooplankton Diversity across Temporary Pools in a Semiarid Intermittent River. International Journal of Biodiversity. 2013;2013:1-13. Available from: https://dx.doi.org/10.1155/2013/946361.

17) Mancinelli G, Mali S, Belmonte G. Species Richness and Taxonomic Distinctness of Zooplankton in Ponds and Small Lakes from Albania and North Macedonia: The Role of Bioclimatic Factors. Water. 2019;11:1-25. Available from: https://dx.doi.org/10.3390/w11112384.

18) Xiong W, Huang X, Chen Y, Fu R, Du X, Chen X, et al. Zooplankton biodiversity monitoring in polluted freshwater ecosystems: A technical review. Environmental Science and Ecotechnology. 2020;1:1-11. Available from: https://dx.doi.org/10.1016/j.ese.2019.100008.

19) Baird W. Description of two new species of Entomostracous Crustacea from India. In: Proceedings of Zoological Society. 1860;p. $213-234$.

20) Anderson HH. Notes on Indian Rotifera. Journal of Asiatic Society Bengal. 1889;58(2):345-358.

21) Sharma PC, Pant MC. Abundance and Community Structure of Limnetic Zooplankters in Kumaun Lakes, India. Internationale Revue der gesamten Hydrobiologie und Hydrographie. 1984;69:91-109. Available from: https://dx.doi.org/10.1002/iroh.19840690109.

22) Sharma BK, Brachionidae I. Eurotatoria: Monogonota) and their distribution. Hydrobiologia. 1987;144:269-275. Available from: 10.1007/BF00005561.

23) Sharma BK, Michael RG. Review of taxonomic studies on freshwater Cladocera from India with remarks on biogeography. Hydrobiologia. 1987;145(1):2933. Available from: https://dx.doi.org/10.1007/bf02530262.

24) Sharma BK, Sumitra S. Taxonomic notes on some interesting cladocerans (Crustacea: Branchiopoda: Cladocera) from Assam (N.E. India). Records of Zoological Survey of India . 2010;110:39-47. Available from: http://faunaofindia.nic.in/PDFVolumes/records/110/02/0039-0047.pdf.

25) Sharma BK, Sumitra S. Faunal diversity of Cladocera (Crustacea: Branchiopoda) in wetlands of Majuli (the largest river island. Opuscula Zoologica Budapest. 2014;45(1):83-94. Available from: https://core.ac.uk/download/pdf/42934766.pdf.

26) Reddy YR. Neodiaptomus prateek n. sp., a new freshwater copepod from Assam, India, with critical review of generic assignment of Neodiaptomus spp. and a note on diaptomid species richness (Calanoida: Diaptomidae). Journal of Crustacean Biology. 2013;33(6):849-865. Available from: https: //dx.doi.org/10.1163/1937240x-00002195.

27) Gaikwad SR, Ingle KN, Thorat SR. Study of zooplankton emergence pattern and resting egg diversity of recently dried waterbodies in North Maharashtra region. Journal of Environmental Biology. 2008;29(3):353-356.

28) Ramakrishna. Limnological investigation and distribution of micro and macro invertebrates and vertebrates of Fox Sagar lake. Hyderabad Records of Zoological Survey of India. 2000;98:169-196.

29) Karuthapandi M, Rao DV, Xavier BI, Deepa J. Zooplankton diversity and trophic status of Safilguda tank, Hyderabad. International Journal of Advanced Life Sciences. 2013;6(1):1-8.

30) Karuthapandi M, Rao DV, B IX. Zooplankton diversity of Osmansagar Reservoir, Telangana, India. Proceedings of the Zoological Society. 2016. Available from: 10.1007/s12595-016-0194-7.

31) Mihir RK, Shabuddin S, Ranga RY, Pai K. A new species of Megadiaptomus Kiefer, 1936 (Copepoda: Calanoida: Diaptomidae) from the Western Ghats of India, with notes on the biogeography and conservation status of the species of the genus. Journal of Crustacean Biology. 1936;38(1):66-78. Available from: https://doi.org/10.1093/jcbiol/rux097.

32) Sharma BK. First report of freshwater rotifers (Rotifera: Eurotatoria) from south Andaman, India: Composition and interesting elements. Journal of Asia-Pacific Biodiversity. 2017;10(2):261-266. Available from: https://doi.org/10.1016/j.japb.2017.01.003.

33) Kudari VA, Kadadevaru GG, Kanamadi RD. Characterization of selected lentic habitats of Dharwad, Haveri and Uttar Kannada districts of Karnataka state. India Environmental Monitoring and Assessment. 2006;120:387-405. Available from: 10.1007/s10661-005-9069-5.

34) Kudari VA, Kanamadi RD. Impact of changed trophic status on the zooplankton composition in six water bodies of Dharwad district, Karnataka state (South India). Environmental Monitoring and Assessment. 2008;144:301-313. Available from: https://dx.doi.org/10.1007/s10661-007-9993-7. 
35) Kiran BR, Puttaiah ET, Kamath D. Diversity and seasonal fluctuation of zooplankton in fish pond of Bhadra fish farm, Karnataka. Zoos' Print Journal. 2007;22(12):2935-2936. Available from: https://dx.doi.org/10.11609/jott.zpj.1464.2935-6.

36) Beenamma J, Sadanand MY. Monthly changes in the abundance and biomass of zooplankton and water quality parameters in Kukkarahalli Lake of Mysore. India Journal of Environmental Biology. 2011;32:551-557.

37) Savita N, Sadanand M. Studies on abundance of zooplanktons in lakes of Mysore, India. Journal of Environmental Biology. 2012;33:1079-1085.

38) Hulyal SB, Kaliwal BB. Water quality assessment of Almatti Reservoir of Bijapur (Karnataka State, India) with special reference to zooplankton. Environmental Monitoring and Assessment. 2008;139(1-3):299-306. Available from: https://dx.doi.org/10.1007/s10661-007-9835-7.

39) Rajashekhar M, Vijaykumar K, Zeba P. Zooplankton diversity of three freshwater lakes with relation to trophic status. International Journal of Systems Biology. 2009;1(2):32-37.

40) Suresh B, Manjappa S, Puttaiah ET. The contents of zooplankton of the Tungabhadra river, near Harihar, Karnataka and the saprobiological analysis of water quality. Journal of Ecology and the Natural Environment. 2009;1(9):196-200.

41) Sunkad BN, Patil HS. Water quality assessment of Fort lake of Belgaum (Karnataka) with special reference to zooplankton. Journal of Environmental Biology. 2004;25(1):99-102.

42) Shivashankar SA. A study on zooplankton diversity of Sogal pond in Belagavi District, North Karnataka. International Journal of Innovative Research in Science, Engineering and Technology. 2017;6(9):19071-19074. Available from: 10.15680/IJIRSET.2017.0609038.

43) Standard methods for examination of water, sewage and waste water. 15thedn. Washington DC. American Public Health Association. 1980.

44) Sharma BK, Michael RG. Synopsis of taxonomic studies on Indian rotatoria. Hydrobiologia. 1980;73(1-3):229-236. Available from: https://dx.doi.org/10. 1007/bf00019452.

45) Patil SH. Asymptotic wavefunctions for two-electron systems;vol. 23. Dharwad. IOP Publishing. 1990. Available from: https://dx.doi.org/10.1088/09534075/23/1/004. doi:10.1088/0953-4075/23/1/004.

46) Dhanapathi M. Taxonomic notes on the rotifers from India (from 1889-2000). Indian Association of Aquatic Biology. 2000;p. 1-178.

47) Khan RA. Faunal diversity of zooplankton in freshwater wetlands of south eastern West Bengal. Records of the Zoological Survey of India. Occasional Paper No. 2003;204:1-107.

48) George MR, Sharma BK, Zoological Survey of India. Indian Cladocera (Crustacea Branchiopoda Cladocera). In: Fauna of India . 1988;p. 1-283. Available from: http://faunaofindia.nic.in/PDFVolumes/fi/023/index.pdf.

49) Sheil RJ. A guide to identification of rotifers, cladocerans and copepods from Australian inland waters. Co-operative Research Centre for Freshwater Ecology. Murray-Darling Freshwater Research Centre. Albury. 1995.

50) Doan KNDP, Van L, Thinguyetnga, Dang N, Thanh H, Thanh H. Identification Handbook of Freshwater Zooplankton of the Mekong River and its Tributaries. Mekong River Commission, Vientiane.. 2015. Available from: https://www.mrcmekong.org/assets/Publications/tech-No45-handbookfreshwater.pdf.

51) Sharma BK, Sumitra S. Crustacea: Branchiopoda (Cladocera). In: Chandra K, Gopi K, Rao D, Valarmathi K, Alfred J, editors. Current Status of Freshwater Faunal Diversity in India. 2017;p. 199-223. Available from: https:/www.researchgate.net/profile/KailashChandra/publication/317184132_Current_ Status_of_Freshwater_Faunal_Diversity_in_India/links/5946577645851525f8997f4e/Current-Status-of-Freshwater-Faunal-Diversity-in-India.pdf.

52) Karuthapandi M, Rao DV. Crustacea: Ostracoda (Seed shrimps). In: Chandra K, Gopi KC, Rao DV, Valarmathi K, Alfred JRB, editors. In: Current Status of Freshwater Faunal Diversity in India. 2017;p. 253-271.

53) Manickam N, Bhavan PS, Santhanam P, Muralisankar T, Srinivasan V. Seasonal Variations of Zooplankton Diversity in a Perennial Reservoir at Thoppaiyar. Austin Journal of Aquaculture and Marine Biology. 2014;1(1):1-7.

54) Shivashankar P, Venkataramana GV. Zooplankton diversity and their seasonal variations of Bhadra Reservoir. International Research Journal of Environment Sciences. 2013;2(5):87-91.

55) Sharma A, Sharma M. Zooplankton Diversity in Relation to Physico-Chemical Parameters in Subtropical Pond of Jammu, Jammu and Kashmir, India. Biosciences, Biotechnology Research Asia. 2019;16(2):425-439. Available from: https://dx.doi.org/10.13005/bbra/2758.

56) Deshmukh US. Ecological Studies of Chattri Lake Amravati With Special Reference to Planktons and Productivity. 2001. Available from: https: //shodhganga.inflibnet.ac.in/handle/10603/13212? mode=full.

57) Rajashekhar M, Vijaykumar K, Zeba P. Seasonal variations of zooplankton community in freshwater reservoir Gulbarga District. International Journal of Systems Biology. 2010;2(1):6-11.

58) Sharma DK, Singh RP. Seasonal variation in zooplankton diversity in Tighra Reservoir. Indian Journal of Scientific and Research. $2010 ; 3(2): 155-161$.

59) Contreras J, Jimenez, Sarma S, Martin MI, Nandini S. Seasonal changes in the rotifer (Rotifera) diversity from a tropical high altitude reservoir. Journal of Environmental Biology. 2009;30(2):191-195.

60) Singh SP, Pathak D, Singh R. Hydrobiological studies of two ponds of Satna (M.P). vol. 8. 2002;p. 289-292.

61) Rajagopal T, Thangamani A, Sevarkodiyone SP, Sekar M, Archunan G. Zooplankton diversity and physico-chemical conditions in three perennial ponds of Virudhunagar district. Tamil Nadu Journal of Environmental Biology. 2010;31:265-272.

62) Manickam N, Bhavan PS, Santhanam P, Bhuvaneswari R, Muralisankar T, Srinivasan V, et al. Impact of seasonal changes in zooplankton biodiversity in Ukkadam Lake, Coimbatore, Tamil Nadu, India, and potential future implications of climate change. The Journal of Basic and Applied Zoology. 2018;79(1):15. Available from: https://dx.doi.org/10.1186/s41936-018-0029-3.

63) Hutchinson GE. Introduction to biology and the limnoplankton. A treatise on limnology. 1967;II.

64) Raghunathan MB, Kumar S, R. 2006. Available from: http://faunaofindia.nic.in/PDFVolumes/records/106/02/0067-0078.pdf.

65) Dede AN, Deshmukh AL. Study on zooplankton composition and seasonal variation in Bhima river near Ramvadi village. International Journal of Current Microbiology and Applied Sciences. 2015;4(3):297-306.

66) Akbulut A. The Diatom Composition of the Salt Lake Basin and Its Relationship with Salinity. Ekoloji. 2010;74:150-159. Available from: https: //doi.org/10.5053/ekoloji.2010.7418.

67) Frey DG. The penetration of cladocerans into saline waters. Saline Lakes V. 1993;p. 233-248.

68) Angeler DG, Alvarez-Cobelas M, Sánchez-Carrillo S. Evaluating environmental conditions of a temporary pond complex using rotifer emergence from dry soils. Ecological Indicators. 2010;10(2):545-549. Available from: https://dx.doi.org/10.1016/j.ecolind.2009.07.001.

69) Green AJ, Fuentes C, Moreno-Ostos E, da Silva SLR. Factors influencing cladoceran abundance and species richness in brackish lakes in Eastern Spain. Annales de Limnologie - International Journal of Limnology. 2005;41(2):73-81. Available from: https://dx.doi.org/10.1051/limn/2005010.

70) Dwyer FJ, Burch SA, Ingersoll CG, Hunn JB. Toxicity of trace element and salinity mixtures to stripped bass (Morone saxatilis) and Daphnia magna. Environmental Toxicology and Chemistry. 1992;11(4):513-520. 
71) Jeppesen E, Søndergaard M, Kanstrup E, Petersen B, Eriksen RB, Hammershøj M, et al. Does the impact of nutrients on the biological structure and function of brackish and freshwater lakes differ? Hydrobiologia. 1994;275-276(1):15-30. Available from: https://dx.doi.org/10.1007/bf00026696.

72) Fryer G. Variation in acid tolerance of certain freshwater crustaceans in different natural waters. Hydrobiologia. 1993;250(2):119-125. Available from: https://dx.doi.org/10.1007/bf00008233. doi:10.1007/bf00008233. 